\title{
PROBLEMS IN MUNICIPAL FINANCE
}

\author{
WALTER F. SCHEFFER \\ University of Oklahoma
}

\section{$\mathrm{M}$} ETROPOLITAN GOVERNMENT and its attendant problems are the sub:ect of considerable recent publication. ${ }^{1}$ Demographic and empirical findings justify this volume of publication which is concerned mainly with the pattern of urbanization and suburbanization now occurring in the United States. Each new census confirms the trend toward an increased urbanization so that today by Census Bureau definition, over two out of three Americans are urban, or only one out of every eight individuals is classified as ruralfarm. ${ }^{2}$ The drama of bigness in the metropolitan phenomenon overshadows the less dramatic existence of the small and medium sized city and its problems. The fact remains, however, that incorporated cities of less than 50,000 population accounted for over 50 million or 28.2 per cent of the total population in 1960 as compared with over 64 million or 36.2 per cent living in cities of over 50,000 . If cities up to 100,000 population are considered as a group, 35.9 per cent of the population is accounted for as compared with 28.5 per cent in cities of over 100,000 people. $^{3}$

Though many of the smaller cities are within the metropolitan complexes and as such are a part of the problem of the metropolitan areas, there are still millions of urban Americans living in cities in which problems of the magnitude of those identified with the larger metropolitan centers do not exist. The problems confronting these smaller and medium sized cities, however, often are as difficult to solve, given the available resources as compared with the larger cities. The fact is that the social, economic, demographic, and technological changes that are having so profound an effect on our great urban centers also leave their mark on the smaller cities and communities. The problems of the large and small urban development are more a matter of degree. Where the metropolitan city may be involved in many area and regional-wide problems in services, planning, decision-making, financing, and a host of other matters, ${ }^{4}$ the smaller city, existing

${ }^{1}$ Besides the volumes of articles, monographs, papers, and speeches of recent date and scores of surveys of individual metropolitan cities in the past decade, including the New York Metropolitan Region Study by Harvard University Press, a representative number of books and studies of length include: John C. Bollens, The States and the Metropolitan Problem (Chicago: Council of State Governments, 1956); The Editors of Fortune, The Exploding Metropolis (Garden City: Doubleday, 1957); Robert M. Fisher (ed.), The Metropolis in Modern Life (Garden City: Doubleday, 1955); Martin Meyerson, Barbara Terrett, and Paul Ylvisaker (eds.), "Metropolis in Ferment," Annals of the American Academy of Political and Social Science, Vol. 314 (November 1957); William A. Robson, Great Cities of the World (New York: Macmillan, 1957); Robert C. Wood, Suburbia: Its People and Their Politics (Boston: Houghton Mifflin, 1959); and Daedalus, Journal of the American Academy of Arts and Science, "The Future Metropolis," Winter 1961.

${ }^{2}$ U.S. Bureau of the Census, Statistical Abstract of the United States, 1961 (82nd annual ed.; Washington, D.C., 1961), p. 613. Under the 1960 Census definition of farm population, the ratio is 1 to 10 .

${ }^{3}$ Ibid., p. 23. These percentages exclude unincorporated parts of urbanized areas, equal to 5.5 per cent of the total population.

- Several recent general statements of these problems are found in: Committee for Economic Development, Guiding Metropolitan Growth (New York: August, 1960); Robert C. Wood, 
outside and often within the metropolitan area, is primarily immersed in the problem of supplying adequate services to its population, while other matters remain peripheral to these basic services. The problem is usually that of securing financial resources adequate to meet the increasing demands for more and better services. This concern is basic to large metropolitan government also, but the smaller urban communities have not seriously recognized public responsibilities which go beyond the traditional service function.

The purpose of this paper is to take a look at the problem of municipal finance of smaller cities by focusing attention on cities of a particular state Oklahoma - and to establish the extent of the revenue problem under which these cities operate, to make some comparisons with cities in other states, and to suggest measures which might improve their general financial plight. A study of this nature might well begin with a brief analysis of the city resident.

The American city-dweller is a complex being. He is a composite of many conflicting values of our society. Myths, fears, anxieties, loneliness, insecurity, indifferences, prejudice, status-seeking - all are a part of the urbanite to a greater or lesser degree. ${ }^{5}$ Furthermore, many identify themselves with the broadly stated and acceptable precepts of past eras. ${ }^{6}$ How many today accept the precept which states: "that government is best that governs least," or the popular principle of "government hands off," or "rugged individualism," or the belief that whatever can produce profits must not fall into the hands of government, that capitalism means democracy, and that to save democracy government must be kept small, weak, and poor? These clichés and hackneyed assumptions have deep roots in our people, even though they are readily ignored when practical sense and selfishness must be satisfied. Thus, we must not permit the city to take over a city bus line, or a water system, or a golf course, or a museum or other educational or recreational enterprise, or one of the utilities so long as any of them show profitable operations. When the red ink begins to show on the ledger, it becomes a government responsibility to subsidize or to assume the function, and no soul-searching about the great guiding principles for a free people is necessary. In New York City today there is a possibility that the rail commuter service will break down completely if government does not step in with public financial aid or take over the commuter trains as a public function. ${ }^{7}$

What does this add up to? For one thing, much of what is the plight of the American city, and certainly the Oklahoma city, is traceable to the question:

Metropolis Against Itself (New York: Committee for Economic Development, March 1959); Wilfred Owen, The Metropolitan Transportation Problem (Washington: Brookings, 1957); Luther Gulick, Metro, Changing Problems and Lines of Attack (Washington: Government Affairs Institute, 1957).

"An analysis of what the individual is today in American society is summarized in Charles $\mathrm{R}$. Adrian, State and Local Governments (New York: McGraw-Hill, 1960), chaps. 2-4. Also see David Reisman, The Lonely Crowd (Garden City: Doubleday, 1950); Erich Fromm, Escape From Freedom (New York: Rinehart, 1941); Margaret Mary Wood, Paths of Loneliness: The Individual Isolated in Modern Society (New York: Columbia University Press, 1953).

- Wood, Suburbia, chap. 2.

"New York Times, September 1, 1960, 26:2; Edward T. Chase, "How to Rescue New York from Its Port Authority," Harper's Magazine, 220 (June 1960), 67ff. 
"What is it that the people in the city want?" We have to determine first whether demand for more services is legitimate. Are the people ready to sacrifice somewhere else to make it possible to extend and improve specific services? In our personal lives we are constantly making decisions which reflect our particular value system. We pick and choose within and sometimes outside our means. With limited resources, it may be a new car, or a comfortable and gracious home, or entertainment and prolonged vacations, or savings for the education of our children, or advancement of our careers or businesses. In each instance, the decision reflects what the individual considers important and thereby satisfies his set of values.

The first prerequisite for the improvement of municipal finance is to create the setting for that improvement. We cannot expect one to have a desire to see a great work of art until he is made aware of art, and he cannot appreciate a work of art until he has been exposed to it. Likewise, in the case of the problem of the city, a real desire for improvement must first exist before the city can expect favorable response. This desire can be generated in large measure by the city. Under energetic imaginative leadership supported by sound and comprehensive long-term planning, people can be made aware of alternatives from which they can pick and choose. With information and education people can usually be expected to seek advancement and improvement because they become restless with the status quo. The advertising profession appears to understand this well. As the people make the choice for improved public services and perhaps sacrifice to do it, they will not want to lose it. As they become the recipients of better public services, an appreciation of them is likely. There are few who would return, if given the chance, to the broken and pot-holed street after having enjoyed a new street, even if it meant a return of the financial investment.

Much more could and should be said on the problem of educating the people to think favorably of public improvements. Public relations is basic for democracy to work constructively. ${ }^{8}$ Other factors, however, which cause financial distress to cities need consideration.

Population can be one of these factors. There is a continuous effort made in many communities to bring people into the city, to invite businesses or manufacturers to town, to keep a running account of daily increases of population as evidence of the blessings of the city so that more may choose to come to a particular city. Population in itself, however, does not necessarily bring better services to a city. It may advance some private interests and if it is a constructive population increase, it may help the whole community. As cities grow, they move from supplying the basic necessities of government (which are relatively easy to finance), to providing conveniences (which increase the total per capita cost), to extending luxury services (which impose still higher per capita costs). Service costs tend to increase in total and in per capita costs as cities become larger. ${ }^{9}$

\footnotetext{
See Public Management, Vol. 42 (December 1960), for recent efforts made by cities in public relations.

- William Anderson and Edward W. Wiedner, American City Government (New York: Holt, 1950), p. 58; Charles M. Kneier, City Government in the United States (3rd ed.; New York: Harper, 1957), pp. 27-28. Also see Otis Dudley Duncan, "Optimum Size of Cities,"
} 
Each new influx of people into suburbia is estimated to result in service costs considerably greater than the contribution the increased population makes to the city treasuries. The Committee for Economic Development reported, as recently as August 1960, estimates of capital outlays for public services ranging from $\$ 2,500$ to $\$ 3,500$ or more for each new house in a suburban development. ${ }^{10}$ The per capita costs of municipal facilities and services tend to increase geometrically rather than arithmetically. The complexities and new demands and requirements upon the governments of the larger cities which the additional population generates impose a considerably higher per capita cost for government. With more than three million added to the national population each year, the expansion of our cities will go on, but before individual cities embark upon great expansion programs, artificially inspired, it might be well for them to consider all facets and their consequences. In 1959 New York City $(7,800,000)^{11}$ had a per capita expenditure of around $\$ 280,{ }^{12}$ while Oklahoma City's $(330,000)$ was over $\$ 40 .{ }^{13}$ It must be recognized, of course, that in the larger cities there are many high tax-producing sources which may have the effect of relieving some of the burden on the individual taxpayer.

Another cause for the distress of the city in most states is traceable to legislative ineptness and misrepresentation. ${ }^{14}$ In 1960 Oklahoma was 63 per cent urban by the Census Bureau's definition. The Bureau's preliminary reports for 1960 show that sixty-six counties lost population in Oklahoma while eleven counties show an increase in excess of 269,000. Oklahoma and Tulsa counties account for about 202,000, while four other counties combined added about 59,500. ${ }^{15}$

Despite a continuing urbanization, the Oklahoma legislature remains ridiculously overpopulated with rural representatives. With the failure to win reapportionment of the legislature in a special election in September 1960, the long existent underrepresentation of city needs will continue even though, at this writing, some success through the initiative and referendum procedure has been made to reapportion according to the constitutional formula, which, however, favors the rural population. At present less than 27 per cent of the people control the majority of representatives while less than 25 per cent control the majority of the Senate. ${ }^{16}$

The generally unsympathetic attitude of the legislature toward the problems of the city is well known. In defense of the legislatures, some point to the relatively favorable vote count on support given by rural representatives to urban

in Paul K. Hatt and Albert J. Reiss (eds.), Cities and Society (Glencoe: Free Press, 1957), pp. 759-72, for an examination of value criteria and statistics on optimum size for cities.

${ }^{10}$ Guiding Metropolitan Growth, p. 21.

${ }^{11}$ New York Times, May 11, 1959, 29:3.

${ }^{12}$ Ibid., April 2, 1959, 22:3. Includes approximately $\$ 70$ per capita for the Department of Education.

${ }^{13}$ Daily Oklahoman, July 1, 1959, 1:3.

${ }^{14}$ Manning J. Dauer and Robert G. Kelsay, "Unrepresentative States," National Municipal Review, 49 (December 1955), $571 \mathrm{ff}$.

1s The Bureau of Government Research, Legislative Apportionment, 1960 (Norman: University of Oklahoma, August 1960), pp. 1-2.

${ }^{16}$ Ibid., pp. 6, 10. 
legislation. ${ }^{17}$ The significant point is that legislation to help cities often does not reach the voting stage because the rural leaders in control are able to kill it in the initial stages, or worst, urban interests fail to bring up matters because of the futility of the situation. Therefore, that which is permitted to go before the legislature is likely to receive some affirmative votes from the rural legislator, which makes his voting record look better than it really is. The imbalance in financial allocations to rural and urban areas is impressive evidence of the domination of rural attitudes and values in the legislatures. The reluctance of rural representatives in Oklahoma extends to refusing cities authority to tax their own residents. ${ }^{18}$ In finance and in other areas of urban concerns the attitude of many legislatures in the United States forces the cities, especially the larger ones, to look beyond the state for help with their mounting problems. Legislators, however, deplore the trend toward Washington.

The municipal finance problem in Oklahoma is perpetuated by the extreme constitutional and statutory restrictions placed upon all cities, whether home rule or statutory. The Constitution of Oklahoma is confusing on the subject of local taxation, resulting in judicial decisions favoring legislative supremacy over virtually all taxing power of the municipality, irrespective of home rule. ${ }^{19}$ In 1924 the Oklahoma Supreme Court held that the municipality did not have the power to assess ad valorem taxes. ${ }^{20}$ Since that decision other taxes have been held to be equally subject to legislative authority. The general consequence of these judicial decisions is a denial of municipal authority to impose special taxes except by legislative authorization.

Controls over budget and public utility management further complicate efforts of Oklahoma cities to meet their financial needs. The power of the county excise boards ${ }^{21}$ to review city budgets allows them to determine the cities' share of ad valorem revenue. In 1957, seven out of twenty-three cities in Oklahoma with more than 10,000 population received no ad valorem revenue for current operations, while ten other cities received two mills or less. ${ }^{22}$ In 1958 Oklahoma City received from a three-mill levy $\$ 746,888$ out of total revenues collected amounting to nearly $\$ 11$ million for operating purposes. From a five-mill levy,

${ }^{27}$ David R. Dirge, "Metropolitan and Outstate Alignments in Illinois and Missouri Legislative Delegations," American Political Science Review, 52 (December 1958), 1051-65.

${ }^{18}$ For exception see footnotes 26 and 28.

${ }^{19}$ Though a case can be made to the contrary for home-rule cities, they have assumed otherwise in light of existing decisions. See Maurice H. Merrill, "Constitutional Home Rule for Cities: Oklahoma Version," 5 Okla. L. Rev. 179-86 (1952).

${ }^{20}$ City of Sapulpa v. Land, 223 P. 640 (1924). In 1917 the Oklahoma Court held in Collinswille v. Ward, 165 P. 1145, that taxation for local needs was of local concern and was a power of the municipality. This rule was modified by Sapulpa v. Land only in the case of ad valorem taxes. Despite this fact, the 1924 decision had the general practical effect of overruling the earlier decision. Also see Ryan v. Roach Drug Co., 239 P. 912 (1925).

${ }^{21}$ Each of the 77 county excise boards is composed of three members - one appointed by the county commission, one by the district court, and one by the State Tax Commission. The history of these boards is one of favoring the needs of schools and counties in the allocation of the constitutional fifteen mill ad valoren tax assessment.

${ }^{22}$ The Governor's Economic Development Commission, Report on Oklahoma's Economy, December 1958, pp. 90-94. 
Enid (39,000 population) obtained approximately $\$ 125,000$ out of total collections of $\$ 1,275,000$ during the same period.

Approximately 17 per cent of all 1956 property taxes collected in Oklahoma was for city purposes. Most of this revenue went into sinking funds which require property tax assessments and are outside the constitutional limit of fifteen mills for county, school, and city operating purposes. ${ }^{23}$ The Census Bureau in 1957 estimated that property taxes accounted for less than 20 per cent of general city revenue in Oklahoma, ${ }^{24}$ which included taxes for indebtedness. Nationally, property taxes in 1959 accounted for nearly three-fourths of city-imposed tax revenues and amounted to approximately 45 per cent of general revenues. ${ }^{25}$

The productivity of the property tax in Oklahoma is seriously affected by generally low assessments on both tangible and intangible properties. An additional factor causing low returns is the list of exemptions allowable by the state constitution and statutes. In 1935 an amendment to the constitution allowed the legislature to exempt homesteads from all forms of ad valorem taxes. The amendment also provided that the exemption allowed by the legislature was to be "in force for not less than twenty years and thereafter until repealed or amended. ..." ${ }^{26}$ The legislature provided for $\$ 1,000$ exemption on homesteads, which became effective on January 1, 1937, and remains in effect in this form today. ${ }^{27}$

There were four other states in 1957, all located in the South, which allowed homestead exemptions. Through this exemption from local property taxes, these five states accounted for over half, or $\$ 4.2$ billion, of the national total assessed value of partial exemptions. Oklahoma's share amounted to $\$ 363,000,000$ lost to local assessments. ${ }^{28}$ The amount of revenue lost to all Oklahoma cities resulting from this one exemption is not available; however, an official study found a combined loss in excess of $\$ 11,357,000$ in tax revenue resulting from homestead exemptions in all cities with a population of 10,000 or more. ${ }^{29}$ This does not represent a loss to the cities only, because these additional dollars would have been divided among the local jurisdictions had it been collectable. In 1960 urban homestead exemptions in Oklahoma amounted to nearly $\$ 320,000,000 .^{30}$

Oklahoma does not allow a partial property tax exemption to veterans as do fourteen other states, ${ }^{31}$ but there are many other total and partial exemptions. Total exempt real property falls in the category of publicly beneficial purposes,

${ }^{23}$ Constitution of Oklahoma, Art. X, sec. 9.

${ }^{24}$ Bureau of the Census, State and Local Government Finances in 1957, Advance Release (Washington, D.C., February 1959), p. 62.

${ }^{25}$ Bureau of the Census, Summary of City Government Finances in 1959 (Washington, D.C., 1959), p. 5.

"Constitution of Oklahoma, Art. XII-A, secs. 1 and 2.

${ }^{27}$ Oklahoma Statutes, 1951, Title 68, secs. 34 and 35.

${ }^{28}$ Bureau of the Census, Property Tax Assessments in the United States, No. 5 (Washington, D.C., December 16, 1957), p. 6 . Iowa and North Dakota also provide for homestead exemptions, but on a tax credit basis up to 25 mills in lowa and on farm homestead improvements in North Dakota.

${ }^{28}$ The Governor's Economic Development Commission, op. cit., p. 89.

${ }^{30}$ Oklahoma Tax Commission, Fourteenth Biennial Report, 1960, p. 244.

${ }^{31}$ Bureau of the Census, Property Tax Assessments. . . op. cit. 
such as religious, educational, charitable, and governmental properties, and certain personal property. ${ }^{32}$ Partial exemptions for Oklahoma were reported to amount to $\$ 57,000,000$ on personal property in $1956 .{ }^{33}$ Eleven other states were reported by the Census Bureau as allowing for smaller to much larger partial exemption.

Because of the constitutional provisions, judicial decisions, and general assessment practices, property taxes cannot bring substantial relief to cities in Oklahoma without basic reforms. What about other taxes? The legislature authorized the levying of occupation taxes, specifying the subjects. ${ }^{34}$ This grant of taxing power never produced much revenue because the court immediately circumscribed its applicability. ${ }^{35}$ It gave a strict construction on what can be included as taxable subjects. Any doubt is resolved against the city. Perhaps it is just as well in this instance, for the occupation tax can produce some serious inequities. In the 1959 session of the legislature, an act was passed which authorized Oklahoma City to levy taxes after popular approval, except sales taxes and other state taxes specifically stated in the statutes as "in lieu of other taxes." ${ }_{36}$ Other than this, there are only the customary license and franchise taxes.

The most lucrative source of revenue for cities is sundry charges, fees, permits, fines, and miscellanea. ${ }^{37}$ Service charges for certain utilities are the source of revenue sustaining Oklahoma cities. Even these charges were questioned as revenue sources until the court removed that doubt a decade ago; however, the reasonableness of charges is still subject to question. ${ }^{38}$ Those Oklahoma cities and towns which established electric generating and/or distribution systems have a better financial ability today. On the basis of one relatively recent study ${ }^{39}$ the revenue from these systems rose from about $\$ 4$ million in 1945 to more than $\$ 10$ million in 1955. About 37 per cent of this revenue in 1955 was net profit to the municipalities. The anticipated property taxes, in contrast, totaled $\$ 1.4$ million. Although the electric rates were higher in these cities than the state average, other utility charges were less. Tax experts believe electric rates are a more equitable basis for taxation than are water rates.

Many people, among them many state legislators, assume that cities are free to select their own sources of revenue. The Oklahoma county excise boards, in

${ }^{32}$ Oklahoma Tax Commission, Oklahoma Ad Valorem and Intangible Personal Property Tax Laws, 1960, pp. 1-3, 65-66.

${ }^{33}$ Bureau of the Census, Property Tax Assessments. .. , op. cit., p. 7.

"Oklahoma Statutes, 1951, Title II, sec. 651.

${ }^{35}$ Representative cases include: Ex Parte Dickison, 280 Pac. 797 (1929); Farley v. Watt, 23 P.2d 687 (1933); Ex Parte Unger, 98 P. 999 (1908); Cains Coffee Co. v. City of Muskogee, 44 P.2d 50 (1935).

${ }^{36}$ Oklahoma Statutes, 1959 Supplement, Title 68, sec. 304. This is another example of the legislature dominated by rural influences refusing to entrust the city legislature with the discretion to tax without popular approval.

${ }^{37}$ As an example, in the university city of Norman, with more than 34,000 population, approximately 76 per cent of general revenue in 1959 was derived from water (46\%), garbage $(21 \%)$, and sewer $(8 \%)$ charges.

${ }^{38}$ Sharp v. Hall, 181 P.2d 972 (1947), Chastain et al. v. Oklahoma City, 258 P.2d 635 (1953).

${ }^{39}$ Stanley Allen Self, "Municipal Electric Utility Systems in Oklahoma" (Ph.D. dissertation, University of Oklahoma, 1958). 
reviewing city budgets, are frequently guilty of the same erroneous assumption. To cite but one instance to show the nature of the limitations the state of Oklahoma imposes upon cities concerning the subject of charging fees, parking meter revenue can be mentioned. For example, in 1958 Oklahoma City obtained in excess of $\$ 310,000$ from parking meters, Tulsa received $\$ 443,000$, and Enid, as a small city, collected about $\$ 80,000.40$ An accurate cost accounting would probably show that these sums represent little more than the cost of regulating parking. Some increase in this revenue may be possible, but the fee which is in excess of the amount needed for meeting the cost of regulation is not legal. ${ }^{41}$ Despite this fact, the cities have often been advised by members of the legislature to try to help themselves by fixing higher parking fees as well as license fees for various private operations. Even if the city had authority to do so, there is a point of diminishing returns, for soon the parking meters in competition with private offstreet parking facilities would stand without customers.

The power of cities in other states to levy property taxes directly or to share liberally in them is general. Chief among nonproperty taxes levied by many cities in the United States are poll taxes, business licenses, and taxes on sales, gross receipts, income, public utility gross receipts, hotel occupancy, liquor, motor vehicles, cigarettes, gasoline, and admissions and amusements. ${ }^{42}$ No city imposes all or even most of these taxes, but the authority is present to levy several of them. Oklahoma cities have the franchise tax on private utilities and since 1959 obtain a small amount of revenue from liquor licenses and some shared revenues from the state-collected road-user taxes. The fact remains, however, that with the generally large property tax take for current expenditures, in conjunction wtih the authority to tax sundry items or operations, cities in other states are better financed than are Oklahoma cities. Residents of Oklahoma cities discover that cities in Texas, Kansas, or some more distant state afford their residents a better life than Oklahoma urbanites enjoy, judging from the appearance and condition of streets, city buildings, utilities, and so on. The fact is that cities of other states often have operating budgets which are twice that of a city in Oklahoma of similar size. A few random examples make this apparent. Oklahoma City had an operational budget of $\$ 10,132,000$ in 1958 ; Fort Worth, a city sufficiently equal in population for comparison, had an operational budget of $\$ 15$,785,000 . In 1950 , Richmond, Virginia, had a population comparable to Oklahoma City; its 1958 operating budget, minus public assistance and education, was about $\$ 18,000,000$. The following Oklahoma cities are in the thirty to forty thousand population range: Enid, Lawton, Muskogee, and Norman. Their operating budgets in 1958 ranged from $\$ 1,000,000$ to $\$ 1,600,000$. In Wisconsin the cities of Eau Claire, Fond du Lac, and Superior are in the same population range but show operating budgets from $\$ 1,800,000$ to $\$ 2,400,000 .^{43}$

\footnotetext{
4n 1958 budgets of the respective cities.

${ }^{41}$ Ex Parte Duncan, 65 P.2d 1015 (1937).

${ }^{42}$ Municipal Finance Officers Association, Municipal Nonproperty Taxes (Chicago, 1951).

${ }^{43}$ Bureau of the Census, Compendium of City Government Finances in 1958 (Washington, D.C., 1958), pp. 56, 58.
} 
Oklahoma cities are not using deficit financing for operations, but the extent of their unsatisfactory financial condition is apparent in the kind of streets, in the deplorable city buildings in many instances, in equipment which is obsolete or in bad repair or in short supply, in sewers which are overtaxed, in police forces that are undermanned and often poorly trained, in low pay and frequently long hours for city employees, and in competition among citizen groups and officials identified with promoting certain services and, naturally, seeking a "lion's share" of available revenues - which "lion's share," incidentally, is usually insufficient to provide an adequate program. These conditions point up the financial state of cities in Oklahoma. When a city street is not properly maintained, deterioration sets in at an accelerated rate and forces reconstruction outlays prematurely, costing more over the long run than does an adequate maintenance budget. The hidden costs to motorists who have damaged tires and other automotive equipment are not sufficiently understood by the people. Then there are the many liability suits growing out of poor sidewalks, poorly maintained equipment, improperly trained personnel, and overused utilities, often resulting in judgments against the city.

A failure to provide adequate revenue for operational requirements results in future indebtedness for replacements and improvements which could have been avoided or handled as part of annual operational costs. For example, a city which requires the purchase of a new fire truck annually to meet growing needs is shortsighted in delaying the purchase for five years and then incurring an indebtedness to buy five trucks to bring the facility up to requirements, perhaps because it is imperative in order to keep insurance rates down.

In the area of capital improvements, Oklahoma cities are constitutionally limited for general bonded indebtedness to 5 per cent of the assessed valuation of property within the city. When property is valued for assessment purposes, as it is in Oklahoma, at about 22 per cent of the average of its marketable value, the constitutional limitation becomes a severe restriction. Some relief from this situation has come through court decisions which held many activities to fall under public utility indebtedness, thereby exempting them from the 5 per cent limit. Public utilities include water, parks, sewers, electric light and power, public fire station buildings and equipment, street-cleaning equipment and machinery, public cemeteries, and convention halls. ${ }^{44} \mathrm{~A}$ further advantage in having public utilities broadly construed by the court is that utility bonds require only a majority vote of the taxpayers, while general bonded indebtedness requires three-fifths of all voters voting on the issue. The fact, however, that all voters can vote in the latter instance may win approval more readily than when only taxpayers vote because some voters falsely assume that only property owners pay the bill. Exempted by court interpretation from the constitutional 5 per cent limitation are: (1) special assessment bonds; (2) the floating debt for the current year not in excess of anticipated revenue; and (3) the floating debt of prior years if evidenced by outstanding warrants rather than judgments or funding debt. The 5 per cent limi-

${ }^{44} \mathrm{H}$. V. Thornton, Readings and Materials in Oklahoma Municipal Government and Administra tion (Norman: University of Oklahoma, 1943), II, 215. 
tation on indebtedness also has been held to apply to the net debt, that is, the bonded debt and judgments less the assets in the sinking fund. ${ }^{45}$

The really serious limitation on indebtedness is found in the prohibition against the issuance of revenue bonds. ${ }^{46}$ The fact that all indebtedness must be met through property taxation makes it difficult to secure approval for needed improvements even when they are revenue-producing. Consequently, other means have been tried with only partial success. One is the lease-purchase arrangement whereby the city enters into an agreement to pay rental on buildings or equipment under a lease until the principal is paid, at which time the city can exercise an option to take possession or let it remain with the private owner. In Oklahoma this has been held illegal because under the constitution, according to the court, lease-purchase is tantamount to creation of an indebtedness because future revenues are obligated; thus approval by the people is necessary and the general limitations on debts apply. ${ }^{47} \mathrm{~A}$ single year's rental agreement is permitted for it falls within current operating expenses.

In many states in recent years there has been a considerable increase in the use of special districts to perform specific operations within or among units of government. Some states have permitted wide use of special districts, but Oklahoma has only a very limited number. ${ }^{48}$ From the standpoint of integrated local government it is better that there be few of them. One of the reasons for their widespread use, however, is to evade constitutional limitations on indebtedness by creating independent taxing units. Where the special districts exist, a threat to the municipality may also develop from overtaxation for the special purpose, thereby reducing the city's tax source. The authority to create these districts in Oklahoma is derived from the legislature and there is no reason to look to this method for capital improvement financing. Generally the special district indebtedness relies upon property taxes; however, those which are revenue-producing usually finance operations and debts through earned revenue. In Oklahoma this latter course remains difficult because of the general prohibition on revenue bonds.

There is some financing of capital improvements in Oklahoma through the instrument of the public charitable trust authorized by legislation in $1951.49 \mathrm{~A}$ representative number of cities have embarked upon this course for capital improvements ranging from electric power plants to sewer and water systems. Oklahoma City used the trust for a number of projects, including airport facilities,

${ }^{15}$ Ibid., pp. 210-11.

* Zachary v. City of Wagoner, 292 P. 345 (1930). Parking stations may be provided by negotiable revenue bonds. Oklahoma Statutes, Title II, secs. 1351 and 1353.

${ }^{47}$ Fairbanks-Morse Co. v. City of Geary, 157 P. 720 (1916); Zachary v. City of Wagoner, 292 P. 345 (1930); City of McAlester v. State, 154 P.2d 579 (1944). A recent case which appears to modify earlier decisions on lease-purchase agreements for water mains in new developments is City of Wewoka v. Billingsley, 331 P.2d 949 (1958). Also see Selected Investments Corp. v. City of Lawton, 304 P.2d 967 (1957).

${ }^{48}$ U.S. Bureau of the Census, U.S. Census of Governments: 1957, Vol. VI, No. 34, Government in Oklahoma (Washington, D.C.: U.S. Government Printing Office, 1959), p. 1. Ninety-two of one hundred and five special districts in Oklahoma are concerned with natural resources conservation.

${ }^{49}$ Oklahoma Statutes, 1959, Title 60, secs. 176-80, as amended, 1953. 
and recently, a major water supply project costing in excess of $\$ 60$ million. Amortization on the latter is to be achieved through increased water rates.

The trust is one answer to the constitutional restriction on revenue bonds, for in it the principle of revenue bond financing can be instituted. The city council can create the trust authorities, composed of city officials or others, who act as trustees for the beneficiary, that is, the city. These authorities, according to the terms of their incorporation, have the power to issue bonds for the particular purpose for which they are created and to provide the method of payment from the property or operation of the trust. Until 1961 legislation requiring voter approval, this was accomplished with or without popular approval. In nearly every instance where it has been used, however, voter approval was first obtained.

In a search for more revenues for cities, the Oklahoma Municipal League proposed diverting to cities some of the state-collected motor vehicle taxes which are earmarked under Oklahoma law for schools. This proposition, however, failed to take into account that one cannot "rob Peter to pay Paul" to solve municipal problems. When nearly 50 per cent of total collections in general sales, income, and motor vehicle taxes are collected in two of the seventy-seven counties, it becomes quite obvious that the cities are producing the great proportion of state revenue. To suggest that motor vehicle taxes, as an example, might be made available in larger proportions to cities with a resulting disadvantage to schools, is not really solving the revenue problem of cities. In all likelihood the very beneficiaries from such a shift in revenues would be required to make a new tax contribution of another or different sort to offset the loss of revenue for education. The search for new municipal revenues today cannot be divorced from the whole haphazard, confusing, and complex tax structure from the local to the national level. The day when only one governmental level imposes a particular tax is pretty well past. Duplication and triplication seem to be the order of the day despite all the federal-state and state-local commissions and groups, public and private, which have suggested principles and formulae for the allocation of tax sources. ${ }^{50}$ In practice nothing substantial results, possibly because the higher levels of government are reluctant to jeopardize for themselves an already uncertain revenue structure. It nevertheless is imperative that there be continued efforts to find additional revenues for cities which are constantly plagued wtih greater demands upon their resources.

Improvement in municipal financing can be accomplished through improved ad valorem tax administration and allocation. In Oklahoma, for example, this means an effective and practical equalization of property valuations within and among counties. The State Board of Equalization is charged with the respon-

${ }^{50}$ Committee on Intergovernmental Fiscal Relations, Federal, State, and Local Government Fiscal Relations (Washington, D.C., 1943); Council of State Governments, State-Local Relations (Chicago, 1946); Council of State Governments, Federal Grants-in-Aid (Chicago, 1949); Commission on Intergovernmental Relations, A Report to the President for Transmittal to the Congress (Washington, D.C., 1955). In 1957, Congress created the joint federal-state action committee which, among other things, studied the federal-state tax problem. This committee was replaced by the advisory commission on intergovernmental relations in 1959. It is reported that this commission is prepared to ask Congress to terminate its operation by 1962 unless some constructive action results from its efforts. See County Officer, 26 (January, 1961), 11. 
sibility to equalize property values among the counties, whereas the county boards of equalization are responsible for this function within the counties. The State Board, however, must lead the way and force the equalization because no county can afford to go far in improving the tax structure without incurring possible losses of state aids to the local units in the county, for some aids are based on local need and production of tax revenue.

Instead of the average 22 per cent, property valuations ought to be the constitutionally required 35 per cent of market value. This would make the fifteenmill limit for operations of counties, schools, and cities more bountiful while at the same time it would provide an opportunity to reduce the over-all rate assessed. Higher limits on general indebtedness would also result. This suggestion assumes that the Oklahoma county excise boards, especially in more populous counties, will eventually recognize the needs of cities and make more than mere token property tax revenues available for operations. If Oklahoma cities, like those in other states, could share in such taxes, considerable relief would be realized.

Cities in Oklahoma undoubtedly would receive some additional revenue from property if the assessments were performed by appointed, rather than elected, assessors. ${ }^{51}$ The need is for a central state agency or division within the State Tax Commission charged with establishing uniform rules, procedures, and guides for determining property values. This agency should have final responsibility for assessors which it should have authority to appoint. Under present administrative practices, the inequalities in assessments within counties often defy understanding. As among the counties, assessment of intangible personal property presents a strange picture, such as the absence in many counties of ownership of stocks and bonds, bank drafts, and other financial holdings. There are no assessments in many counties on such items of personal property as jewelry, electrical equipment, sporting equipment, professional libraries, and many others. $^{52}$

Finally, the homestead exemption should be repealed. This was a depression measure which has little justification today. Homestead ownership would not be discouraged nor threatened. Many homeowners in Oklahoma pay very little, if any, tax on their property. In some counties the valuations are considerably below 20 per cent of true market value, which often relieves the home owner of taxes when the $\$ 1,000$ exemption is applied.

Cities should be granted constitutional or legislative authority to tax as a general power within broadly defined limits. Judicial interpretation of municipal powers has held these powers as grants from the state. The courts might look upon the charters of cities as limitations on the exercise of powers rather than specific grants of power to do certain things only as specifically provided. ${ }^{53}$ This would mean that cities would be freed of many current restrictions. In a sense it regards the powers of cities as a positive rather than a negative grant.

\footnotetext{
${ }^{\mathbf{5 1}}$ The State Board of Equalization assesses railroad and other public utility property.

${ }^{52}$ Oklahoma Tax Commission, Fourteenth Biennial Report, 1960, pp. 174-227.

${ }^{53}$ For examples of this kind of approach to powers of cities, see City of Glendale v. Trondsen, 308 P.2d 1 (1957); Wiley v. City of Berkeley, 288 P.2d 123 (1955); and State ex rel. McClure v. Hagerman, 98 N.E.2d 835 (1951).
} 
If authority to tax as a general power is impractical to suggest, the legislature should at least empower cities to tax more freely and have a larger share of statecollected taxes. Pennsylvania enacted legislation in 1945 which gave to local units of government the right, with some exceptions, to tax anything that the Commonwealth itself did not tax. ${ }^{54}$ This law has worked well on the whole and has produced needed revenue for cities. Other than the property taxes for cities in the nation generally, the income and sales taxes are perhaps the more promising of all the taxes the city might use. On the whole property taxes are diminishing in importance while income and sales are still open to more exploitation. The biggest producer for Oklahoma cities, and second only to property nationally, are charges and miscellanea. But these have their limitations and the probability is that a lesser share of total needs can be obtained from this source in the future.

The American cities are not the best or most natural unit for the collection of a number of taxes which many presently collect. This does not mean that they should not have the proceeds from the taxes. Rather, the state should take the responsibility for collection and return the revenue to the cities. The taxes should come from the area comprising the whole of the metropolitan or urban service area, rather than only a defined central unit. ${ }^{55}$ In the case of Oklahoma City, a reorganized modern county government could assume many functions that are presently the responsibility of the city and, thereby, treat most of the urban complex as one when using the shared taxes or grants. To the extent that services become the responsibility of the county, the city would be better prepared to handle remaining obligations with existing revenues. In smaller cities, the municipality would be the most natural unit for the assessment of taxes and expenditure of the revenues collected by the state and returned to the city. What is needed, in general, is a greatly stepped-up shared-tax and grant-in-aid program from the state level and, to a lesser extent, from the national government.

Another aspect of the problem of finance is planning. No city can expect to achieve proper objectives wtihout planning. The kind of planning needed is that which derives from the physical planning department and more especially from the financial management department. Most needed are sound long-range comprehensive financial plans or programs for guidance in the use and allocation of available revenues. The realities of this need are obvious. A rather simple decision to provide for something today often results in a burdensome or misdirected outlay thereafter. Many policies which appear of little consequence when made have tremendous capacity to grow. The finance department should be equipped to assume the responsibility for long-range planning which can avoid the kind of decision which results in an unintentional future financial burden for the

${ }^{54}$ International City Managers Association, Municipal Year Book, 1960 (Chicago, 1960), p. 200. Philadelphia was invested with a liberal power to tax in 1932 and, subsequently, imposed an income tax in 1938, which produced nearly 33 per cent of the total general fund receipts in 1958. Jewell Case Phillips, "Philadelphia's Income Tax After Twenty Years," National Tax Journal, 11 (September 1958), 241-53. See also Robert A. Sigafoos, The Municipal Income Tax: Its History and Problems (Chicago: Public Administration Service, 1955), esp. chap. 4.

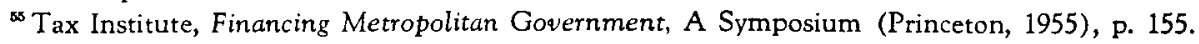


city. Also, and more importantly, planning for future operational and improvement needs affords the decision-makers with alternatives from which to choose. Planning which is constantly kept up to date makes it possible to know total financial needs for the future. For example, when major capital improvements are proposed through bonded indebtedness, the city council can see immediately what the improvement will mean in terms of additional operational costs. Because of this latter factor, it might be wise to delay the action and choose instead another priority improvement which will not strain current revenues to the point of posing a threat to other established programs. Or perhaps, the comprehensive physical and financial plan justifies the original proposed improvement at the cost of other services. The point is that the decision is based upon more than intuition or hunch. It should be mentioned, too, that a long-range general plan is required before a city can approve an Urban Renewal Authority.

A well-prepared plan covering fifteen to twenty-five years for capital investments and service improvements gives the public something to study, to hope for, and to accept as necessary commitments for the good life in the city. Many bond issues in Oklahoma have failed in recent years because they represented nothing more than a shot in the dark by the city and appeared to the voter as unnecessary demands for more taxes. It is doubtful that anyone can successfully contend that these bond issues would not have served a real need in each specific instance. But the people do not have that kind of confidence in their city governments, as they often do in the case of their school boards - that is, to react favorably without first being convinced of the proposal! Planning can and should be an important public relations technique. Although it requires a financial investment to plan, the returns when properly used make the investment highly profitable.

There is no single or simple solution to the money problems of cities in Oklahoma or elsewhere. Of course, individual cities often differ drastically and require different approaches. But as a general problem, there is no panacea to offer. We are confronted with a variety of problems, some of which are difficult to solve as they undergo transmutations and arise in new forms, requiring still different remedies not yet discovered by the urban trouble-shooter. But those ills which we can recognize are not beyond the genius of the citizens to solve. Many, as I have tried to point out, require relatively obvious and specific action for improvement. 